\title{
Electoral Integrity and Support for Democracy in Belarus, Russia and Ukraine
}

\author{
http://authorservices.taylorandfrancis.com/sharing-your-work/ \\ This is an Accepted Manuscript of an article published by Taylor \& \\ Francis in Journal of Elections, Public Opinion and Parties on \\ 2015, available online: \\ http://wwww.tandfonline.com/10.1080/17457289.2014.911744
}

\author{
Ian McAllister \\ School of Politics and International Relations \\ Australian National University \\ Canberra, ACT 0200 \\ ian.mcallister@anu.edu.au
}

\author{
Stephen White \\ Department of Politics \\ University of Glasgow \\ Glasgow G12 8RT \\ s.white@socsci.gla.ac.uk
}

An earlier version was delivered at the 'Hybrid Regimes in Central and Eastern Europe and East and Southeast Asia' conference, Center for European Studies, The Australian National University, 16-17 August 2012. Our thanks to workshop participants, Juliet Pietsch, Mark Franklin and two anonymous reviewers from this journal for their constructive and valuable suggestions. 


\begin{abstract}
The expansion of democracy following the collapse of communism in 1989-90 led many to believe that democratic institutions would rapidly take root. However, over the past decade, electoral malpractice has become widespread, casting doubt on democratic consolidation. This paper examines the causes and consequences of weak electoral integrity in Belarus, Russia and the Ukraine. Using a series of opinion surveys conducted since 2000, we show that public perceptions of electoral unfairness have their roots in seeing widespread corruption among public officials. By contrast, viewing elections as fair correlates with support for the incumbent government, and in watching television, the latter showing the importance to the regimes of control of the mass media. In turn, views about electoral integrity have a significant impact on satisfaction with democracy, especially in Belarus. The results suggest that only root and branch reform in the postcommunist societies will substantially improve public perceptions of electoral integrity.
\end{abstract}




\section{Electoral Integrity and Support for Democracy in Belarus, Russia and Ukraine}

Countries transitioning from authoritarianism to democracy have a wide range of problems to confront, any one of which can derail the transition process. The opening up of the economy to market pressures is invariably accompanied by plunging living standards and intense political and social pressures. In many instances, these pressures are sufficient to tip the country back into authoritarian rule (Linz and Stepan, 1996). At least as important as economic prosperity is the establishment of widely supported democratic institutions. Without such institutions, and the rules and procedures that underpin them, democratic consolidation is unlikely to take root and a return to authoritarianism becomes ever more likely. Key among the institutions that require widespread public support in order to foster democratic consolidation is elections.

The efficient operation of democracy assumes, as a minimum requirement, the existence of free, competitive elections. However, as elections have proliferated around the world in many diverse political and cultural settings, it has become apparent that while elections may often be 'free' by a strict definition of the term, ruling parties and incumbent elites may still exercise such an influence on the outcome that they can hardly be considered 'fair'.

Manipulating the outcome of an election can be achieved in a variety of indirect ways, such as stifling debate or restricting media freedom, so that an election, while nominally competitive and open to no serious objection in the way in which the votes are counted, may all the same be heavily weighted in favour of the governing authorities (Birch, 2012; Schedler, 2006). In fact, undermining an election can occur at any point in the electoral cycle, from the preelection period through to the campaign and its aftermath (Norris, 2012).

A lack of electoral integrity can, of course, have broader implications for the political system as a whole. Political institutions and how they operate reveal messages about the principles and norms of the political culture that shape people's beliefs and values (Galbreath and Rose, 2008). A lack of integrity in electoral institutions undermines the basic principles of fairness and impartiality that lie at the heart of a well-ordered and functioning democratic society. Moreover, a political culture that sustains widespread corruption harms democratic citizenship, by weakening democratic knowledge and citizens' sense of efficacy and trust in the institutions of government (Linde, 2012; Rothstein, 2009). And not least, institutional corruption further encourages low-level societal corruption in a vicious circle that continually undermines public support for democratic values.

This paper tests the hypothesis that the public's perception of electoral fairness in countries transitioning from communism to democracy influences their views of the 
democratic process. Our cases studies are Belarus, Russia and Ukraine, all countries where, more than a decade ago, it appeared that the achievement of full democratization was just a matter of time. In the last decade, however, all three countries (and particularly the first two) have returned to authoritarian rule while still retaining a nominal commitment to free and competitive elections. The first section reviews the research on free elections and their links to democratic consolidation. The second section provides an overview of elections in the three countries, while the third section examines the means by which elections in the three countries have been manipulated as well as the broader context of corruption among public official. The fourth section tests four explanations for beliefs about electoral integrity and evaluates the impact of electoral integrity on satisfaction with democracy.

\section{Electoral Integrity and Democracy}

Since the 1990s, with the rapid expansion of democracy across the world, the fairness of electoral procedures has come under increasing scrutiny. Scholars have examined the forensics of elections, using mathematical formulas in order to detect the existence of systematic malpractice (see, for example, Alvarez, Hall and Hyde, 2008; Myagkov, Ordeshook and Shakin, 2009). This approach hypothesizes that manipulation takes place centrally, normally through electoral management bodies, during or after the formal vote counting procedure. A second theme has been to examine the manipulation of election rules, often involving who can stand for election or gain access to the mass media, in order to restrict free competition (see, for example, Lindberg, 2009; Levitsky and Way, 2010). For this to occur, rules have to be put in place well before the election. And a third theme has involved the scrutiny of election management bodies and the role of international observers in overseeing the integrity of the process (see, for example, Hyde, 2011, Kelley, 2012). The role of electoral management bodies has been particularly sensitive, given the scope for placing partisans in positions of authority where they have considerable scope to falsify the election result.

While these approaches provide important perspectives on electoral integrity, for the most part they ignore perhaps the most important element of an election: how citizens' views of the electoral process influence their attitudes towards democracy and their support for the system as a whole. In most democracies, voting is the one act which involves the majority of the population, and for many it is their only engagement with the political process. As a consequence, a widespread view among the public that election manipulation takes place will arguably undermine public support for democracy, and leave open the possibility of a return to 'more orderly' and predictable authoritarian rule. Equally, if the public sees a high level of integrity in the process, then they will be encouraged to turnout to vote, an act which itself enhances support for democracy (Blais, 2000; Anderson et al, 2005). In principle, then, the 
public's faith in the integrity of their electoral institutions should have a major impact on broad, public support for democracy itself.

Cross-national research already exists on this important aspect of electoral integrity. Sarah Birch $(2008,2010,2012)$ has conducted a series of studies covering electoral integrity across a wide range of countries, including established as well as new democracies. These studies have generally shown a strong link between lack of confidence in the electoral system and weak support for basic democratic values and procedures. In particular, the public funding of parties and proportional representation electoral systems have strong impacts on confidence, more so than confidence in the integrity of the electoral process itself. Counter-intuitively, Birch also shows that independent electoral management bodies are negatively associated with confidence, a finding which she attributes to 'the fact that many such bodies have been introduced in response to perceived problems with impartiality' (Birch, 2008: 313).

Research which has focused on electoral integrity in the postcommunist countries is more limited. Two studies have examined Russia. Using survey data to examine beliefs about the fairness of the 2007 Duma Election, Rose and Mishler (2009: 130) find that 'seeing an election as unfair is likely to make people less proud of their country, less trustful of political institutions, and less supportive of their regime.' However, they also find a strong partisan element in these popular evaluations, so that if one's party is seen to win, then the perceived fairness of the election is largely irrelevant. Using a wider range of surveys conducted over a longer timespan, these findings are largely confirmed by McAllister and White (2011), who see perceptions of fairness declining during the Putin years, which in turn is linked to public views about the widespread nature of corruption in Russian society.

We extend this research in several ways. First, we cover not just Russia but Belarus and Ukraine, two countries with close links to Russia but where the process of democratization has slowed or even reversed. Second, we evaluate possible explanations for public perceptions of electoral fairness, since direct experience of electoral malpractice is minimal. Third, we examine the impact of these beliefs on democratic values and the likelihood of electoral participation. The data come from a series of national surveys conducted by the authors in the three countries since 2000, using the assistance of local agencies; these surveys provide an unrivalled overview of the trajectory of electoral integrity across the three countries. Full details of the surveys are given in the Appendix.

\section{Postcommunist Democratic Consolidation}

Initially, international judgments on postcommunist elections were broadly favourable. The political monopoly of the Marxist-Leninist years had been replaced by a competitive choice of elected representatives underpinned by constitutions that guaranteed the full range of liberal freedoms, including a separation of powers, the rule of law and minority rights. In 
Russia there were guarantees of 'political diversity' and 'multiparty politics'; no ideology could be obligatory, or in any way official. Indeed, there was freedom of information legislation that was not yet available in many of the Western democracies. And remarkably, domestic legislation was explicitly subordinate to the 'generally recognised principles and norms of international law' as well as the treaty commitments into which the state had entered; in the event of any divergence between the two, it was the international treaty that would have precedence. $^{1}$

The elections that took place in the early postcommunist years appeared to bear out these confident predictions. All the republics had moved towards a choice of candidate, if not of party, by the late Soviet period. Russia, from 1993 onwards, had multiparty as well as multicandidate elections, organized in the first instance on a basis by which half the seats in the legislature were filled by contests in single-member constituencies distributed across the country, and the other half by a national party-list contest in which seats were allocated in proportion to votes received provided a 5 percent threshold had been satisfied. The Ukrainian system was based initially on single-seat constituencies; in 1998 and 2002 on a mixed constituency and party-list system; in 2006 and 2007 on the exclusively party-list system that has been in operation in Russia since 2005; and from 2012 onwards it has been organised on a mixed constituency and party-list basis. The Belarusian lower house has been elected throughout on a single-member constituency basis, with successful candidates required to obtain an absolute majority of the ballot.

Initially, international assessments of the quality of this novel process were positive. The OSCE's first observation mission to a Russian parliamentary election, in 1999, reported that the elections represented a 'benchmark in the Federation's advancement toward representative democracy' and a solid turnout had shown a 'respectable level of public confidence in the process' (OSCE, 2000: 1-4). Later reports were less enthusiastic, reflecting a political system in which authoritarian elements had become stronger with the accession of Vladimir Putin in the place of Boris Yeltsin. The 2003 Duma election, the OSCE reported, though 'welladministered', had 'failed to meet a number of OSCE commitments for democratic elections, most notably those pertaining to unimpeded access to the media on a non-discriminatory basis; a clear separation between the state and political parties; and guarantees to enable political parties to compete on the basis of equal treatment (OSCE, 2004: 1). In 2007 and 2008, after a disagreement with the Central Electoral Commission, there was no official mission, but smaller groups of ad hoc observers concluded that the Duma election had 'definitely not [been] fair' in spite of a choice of voting options (Council of Europe Parliamentary Assembly, 2007: point 40) and that the presidential election had 'repeated most of the flaws revealed during the Duma elections of December 2007' (Council of Europe Parliamentary Assembly, 2008: point 33). 
The OSCE mission that took place in December 2011 found that the elections had once again been 'technically well-administered', but that they had also been 'marked by the convergence of the state and the governing party' and 'slanted in favour of the ruling party'. This had been apparent in the lack of independence of the election administration, the partiality of most of the media and undue interference by the state authorities at various levels, all of which had not provided the 'necessary conditions for fair electoral competition'. The quality of the election process, moreover, had 'deteriorated considerably during the count', which had been characterised by 'frequent procedural violations and instances of apparent manipulation, including several serious indications of ballot box stuffing'. Opposition parties had complained about 'undue restrictions on the right to hold rallies', and television coverage had been 'dominated by reports of state officials' activities' (OSCE, 2012: 1-2).

Developments of this kind could scarcely be reconciled with the democratization narrative that had predominated in the early 1990s, and there was a wide measure of agreement with the view that the time had come to 'abandon the transition paradigm' altogether (Carothers, 2002). Ukraine was an exception, after the 2004 Orange Revolution had forced the cancellation of a clearly falsified presidential election and then a new contest in which the pro-Western candidate, Viktor Yushchenko, had been successful. Although some commentaries suggested a regression after the 2010 presidential contest brought his defeated rival, Viktor Yanukovych, to power, international observers remained satisfied with the electoral process itself. The parliamentary election of 2007, they reported, had been 'mostly in line with OSCE and Council of Europe commitments and other international standards for democratic elections' (OSCE 2007: 1) and the 2010 presidential contest itself had been a 'transparent' exercise that had offered voters an 'open and competitive environment' (OSCE 2010: 1).

It was rather different in Belarus, after a constitutional referendum in 1996 (whose legitimacy was not accepted by Western governments) that had given additional powers to the presidency, and then another referendum in 2004 that allowed the incumbent an unlimited number of terms of office. Lukashenko, his opponents agreed, was popular, but not so popular as to obtain nearly 80 percent of the vote in a presidential election in 2010 that showed (in the view of international observers) that Belarus still had a 'considerable way to go in meeting its OSCE commitments for democratic elections' (OSCE 2011: 1). Meanwhile in Russia a 'Putinist system' was developing in which there were elections that effectively excluded a serious challenge to the authorities, a Kremlin-sponsored 'party of power' that held up to twothirds of the seats in the legislature, a 'superpresidency' that monopolised the political agenda, and a regime that dominated the wider society in a manner that had something in common with the 'leading role' that had formerly been enjoyed by the Communist Party of the Soviet Union (Mendras, 2012). 
One summary measure of these changes was the assessment that was regularly provided by the US-based organisation Freedom House. In 1990, a substantially reformed Soviet Union had already been classified as 'partly free'. For some time its postcommunist successor was given a similar rating, but in 2004 it dropped from 'partly free' to 'not free', where it has remained (as of 2013 it was considered to be a 'consolidated authoritarian regime'). Ukraine moved in the opposite direction (as of 2013 it was a 'transitional government or hybrid regime'), but Belarus became 'not free' in 1996 and has remained there since then. Most of the other post-Soviet republics-Azerbaijan, Kazakhstan, Kyrgyzstan, Tajikistan, Turkmenistan and Uzbekistan —-were also classified as 'consolidated authoritarian regimes'; Armenia was 'semi-consolidated'. Of the original 15, only the Baltic states were regarded as 'free' in 2012; and of the others, only Georgia and Moldova as well as Ukraine were as much as 'transitional or hybrid.' 2

This was admittedly only one among a number of attempts that had been made to identify the type of polity that lay in the 'grey zone' between established liberal democracies and unqualified dictatorships; other suggestions ranged as far as 'feudalism' (Shlapentokh, 2007) to 'third world patrimonialism with Bonapartist tendencies' (Marwick, 1999: 127). A proposal that gathered more support in the early 2000s was 'competitive authoritarianism', which was another way of distinguishing a type of regime that combined electoral competition with varying degrees of authoritarianism. Unlike single-party systems and military dictatorships, there was an opposition in regimes of this kind that could vigorously and sometimes successfully compete for power. But the competition in which they engaged was unfair, because of 'electoral manipulation, unfair media access, abuse of state resources, and varying degrees of harassment and violence [that] skewed the playing field in favor of incumbents' (Levitsky and Way, 2010: 3-4). There were 35 states that could be classified in this way in the first half of the 1990s, including Russia and Ukraine as well as four of the other post-Soviet republics. In the next section we examine the ways in which electoral manipulation has taken place in Belarus, Russia and Ukraine.

\section{The Process of Electoral Manipulation}

There were several mechanisms by which outcomes could be manipulated in the authoritarian elections that took place in the three regimes (Schedler, 2006; White et al, 2012). First, the law was frequently changed in ways that were normally to the advantage of the incumbents. The Russian parliamentary election law, for example, was amended 26 times between its adoption in 2005 and the spring of 2012; a particularly important change was the elimination of single-member constituencies and with them the possibility of independent candidates who could articulate the interests of local elites - and sometimes of ordinary citizens - as against the federal authorities. Rules on the nomination of candidates could also 
be changed in ways that made it easier to exclude a potential challenger, such as by faulting the signatures on nomination papers. In Ukraine, more than 400 attempted nominations were rejected on this basis in the parliamentary election of October 2012, mostly for 'minor omissions'; former prime minister Yulia Tymoshenko was excluded from her own party list as she was in prison following what Western governments regarded as a transparently political trial (OSCE, 2013: 15-16).

Second, the electoral commissions in the three countries were disproportionately staffed by regime loyalists. For example, the head of the Central Electoral Commission in Russia, Vladimir Churov, was a long-standing friend of the President who was widely celebrated for his 'first law' - that 'Putin is always right'(Kommersant, 9 April 2007: 1). Regime-favoured parties and candidates could in any case make use of 'administrative resource', or the support of the state itself, in advancing their campaign. Governors, for instance, could take a place on the party list and use the support that was available from their office to campaign without necessarily taking their seats in the legislature. They could issue instructions to their subordinates within the various structures that were financed by the state itself, such as schools and hospitals. And Kremlin-sponsored parties and candidates at all levels could be sure of more extended and favourable treatment in the mass media, especially television. In Ukraine, similarly, there was a 'clear bias' in favour of the President's own Party of the Regions, with 48 percent of all campaign coverage on the state-owned First National channel, and in overwhelmingly positive tones, as compared with 17 percent for its principal competitor (OSCE, 2013: 23).

Third, manipulation could take place on election day itself. There could be pressure to vote, to abstain, or to vote in advance. In Russia there was a mobile voting facility that allowed electors to vote in their own homes in the presence of election officials, but normally beyond the reach of independent observers (more than six million votes were cast in this way in March 2012; in the Ukrainian parliamentary election the following October, the same figure was more than a million). There could be old-fashioned ballot stuffing. And there could be inducements, including cash payments. In the 2007 Russian Duma election, voters were offered a free consultation with a gynecologist or urologist in the polling station itself; in Kemerovo they were invited to sample cheese and spirits (although no more than 100 grams a person); in Tomsk, students were offered free railway tickets; in oil-rich Tyumen, a vote for United Russia could be worth a thousand rubles (at the time, about \$41) (White et al, 2012: 545-6). Payments of this kind were often associated with 'carousel voting', with the same electors voting at a series of polling stations and often doing so in organised groups, in a fleet of buses.

Inevitably, the scale of any election will bring some instances of manipulation or fraud. In Russia, for example, elections encompass nearly 100,000 polling stations spread across a 
seventh of the world's entire land surface; some departure from official practice is unlikely to be avoided. But how much difference has electoral manipulation made? Putin himself thought it 'possible' there had been irregularities - 'probably there were some ... but they can only influence hundredths of a percent. Well, maybe one percent, that I can imagine. But no more' (Daily Telegraph, 8 March 2012: 12). The head of the Central Electoral Commission, Vladimir Churov, routinely pointed out that the officially declared results had been close to the forecasts of the major survey organisations, which was a form of independent confirmation (the CEC compared their results with the agencies' final predictions, which took account of their latest returns but could not legally be published over the five days that preceded polling). The final results were also close to the exit polls that had been reported immediately after the polling stations had completed their business (White et al, 2012: 671).

All the same, in Russia there was some divergence between the survey results and the official figures that one of the largest survey organisations, the All-Russian Centre for the Study of Public Opinion (normally pro-Kremlin), attributed directly to falsification. And there were smaller survey organisations that had successfully predicted the outcome on the basis of a figure that had been 'corrected for administrative resource', which meant that they had been 'attempting to predict the scale of falsification, and not to reflect public opinion as accurately as possible' (Moskovskie novosti, 20 March 2012: 2). On our own evidence, using a Levada survey of 1,600 respondents conducted between 16 and 20 December (in other words two weeks after polling day), 46 percent had voted for United Russia (the official result was 49.3 percent), the Communist Party took 17 percent (the official result was 19.2 percent), and Fair Russia and the Liberal Democrats both took 12 percent (the official results were 13.2 and 11.7 percent respectively) (Rose, 2012: 26). In March 2012, our survey predictions were 61 percent for Putin, as compared with the declared result of 63.6 percent (Rose, 2012: 27).

Finally, any analysis of fairness in postcommunist elections has to take into account the public's perceptions of the level of corruption among public officials. A large proportion of the citizens within the postcommunist states believe that corruption is widespread and that little is being done to combat the problem. Moreover, most believe that in order to get by in their day-to-day lives - whether it is seeing a doctor, gaining a university place for a child, or avoiding a traffic fine - they must 'play the game'. This inevitably involves colluding in a corrupt act. In other words, most citizens in the postcommunist societies believe that the system compels them to engage in corrupt behaviour (Karklins, 2006: 3). Objective indicators of corruption within the public sector endorse the pessimistic views of the general public about Belarus, Russia and Ukraine. In 2012, Transparency International ranked Belarus 123, Russia 133 and Ukraine 144 out of a total of 174 countries on corruption (Transparency International, 2012). Moreover, there has been relatively little change in these rankings during the course of the decade. 
The surveys underpin the view of endemic corruption in Belarus, Russia and the Ukraine. In Russia and Ukraine, Figure 1 shows that a large majority believe that 'most' or 'almost all' public officials are corrupt. Indeed, in 2006 and 2007 more than nine out of every 10 respondents in Ukraine took this view. In Russia there has been a marginal decline in perceptions of corruption over the 2000 to 2012 period, but even so in 2012 almost three in every four respondents believed that corruption among public officials was widespread. The trend in Belarus differs from that observed in Russia and Ukraine, with high levels existing until 2006, and then a marked decline thereafter, dropping to 42 percent in 2011. This reflects efforts by the regime to combat the problem, which have been more effective than elsewhere because of its centralized, authoritarian nature.

[Figure 1 about here]

By any standards, corruption is an endemic problem in the three societies, and more generally within the postcommunist world, regardless of whether or not they are members of the EU (Holmes, 2006; Linde, 2012). These pessimistic conclusions are supported by the objective indicators of corruption provided by independent monitors such as Transparency International. Since corruption starts - and often ends - with government, it would not be surprising if these general views about society-wide corruption were also not reflected in views about electoral fairness. The next section tests a range of explanations to account for the public's perceptions about electoral integrity in each of the three countries.

\section{Results}

Public Perceptions of Electoral Integrity. We begin by examining the measurement of electoral integrity. The concept of electoral integrity has several dimensions. Most obviously, the procedures for counting the ballots must be fair. However, the concept also incorporates aspects of the election campaign that precede the act of voting, such as media coverage and the rules governing political finance. Schedler (2002: 40-41) has identified seven requirements that must be satisfied before an election can be considered fully 'free and fair'. These requirements include: the means by which those who hold power are selected; an unrestricted choice of alternatives; freedom for voters to form their preferences; universal suffrage; freedom for voters to express their preferences; the fair aggregation of votes; and the provision of a mandate to government as a result of an election. Other configurations identify as many as nine aspects (see, for example, Norris, 2012: 12).

The current surveys did not have the extensive range of measures that would have permitted us to evaluate the public's perceptions of electoral fairness over all of these possible dimensions. ${ }^{3}$ The surveys did, however, have three measures of fairness that have been asked consistently from 2000 onwards. These are fairness in terms of: 'the composition of the ballot paper and counting votes'; 'television coverage of the election campaign'; and 'the conduct of 
the electoral campaign in your district'. ${ }^{4}$ These three items cover the major aspects of the election campaign in addition to the act of voting itself. They are strongly correlated ${ }^{5}$ so combining them into a single, composite scale produces a reliable measure of the integrity of the election in each country. We use 'fair' to measure an election against one or more of these criteria; following Rose and Mishler (2009: 118), by placing the emphasis on 'fair' we avoid the catchphrase 'free and fair', in which 'multiple desiderata are indiscriminately lumped together'.

By any standards, the most recent elections in the three countries are viewed by their respective publics as flawed, to varying degrees. In general, the results in Table 1 show that around two-thirds of the respondents view the election as either 'definitely' or 'somewhat' fair; the highest figure is 67 percent in Ukraine for seeing the TV coverage of the campaign as fair. At the other end of the scale, just 52 percent of the Russian respondents regarded the counting of the votes and the local campaign as fair. By combining the three measures into a single scale we can produce a parsimonious measure of the electorate's perception of the overall fairness of the election. Using this metric, the elections in Belarus and Ukraine are regarded as being the fairest (both with a mean of 6.4 on a zero to 10 scale), and Russia as being the least fair (a mean of 5.4).

[Table 1 about here]

By estimating a single measure of electoral integrity for each country we are also able to evaluate the trajectory of change in electoral integrity over an extended period. Figure 2 shows that the decade-long trend across the three countries is towards an increase, albeit a modest one, in the perceived fairness of their respective elections. In Belarus and Ukraine, the change is in the order of half a point on the zero to 10 scale, comparing the first year for which we have data (2000 in both cases) with the last year (2011 for Belarus, and 2010 for Ukraine). In both countries the most substantial increase was in the first half of the decade, with Ukraine showing a decline in 2008 before an increase in 2010. The trend for Russia shows a more gradual increase across the decade, but a substantial decline of 0.6 of a point in 2012, following widespread allegations of malpractice in the presidential election of that year.

[Figure 2 about here]

Explaining Public Perceptions of Electoral Integrity. How are these perceptions of electoral integrity formed? We test four hypotheses to account for these perceptions across three countries. The first hypothesis relates to support for the current regime - an incumbency effect. Since their party is a beneficiary of the electoral system, we would expect supporters of the current government to see greater integrity in the electoral system than opponents, other things being equal. The second hypothesis is that perceptions are a consequence of views about the level of corruption among public officials. Citizens who see more corruption among public officials will be more likely than others to believe that corruption exists in elections. A 
third hypothesis is that these perceptions have their roots in experiences with other democracies, so that respondents compare their own elections with those in the established democracies and find them wanting. This is measured here by whether or not the respondents reported visiting the Baltic states, Poland or the United States, ${ }^{6}$ and the degree to which they identified themselves as European. The fourth and final hypothesis that might explain public opinion about electoral integrity is that perceptions about the election stem from the mass media, measured here by the frequency of watching national television and reading national newspapers.

In order to test these four hypotheses, a series of regression equations was estimated, predicting whether or not the respondents considered their most recent election as fair from a range of independent variables reflecting the four hypotheses. The figures are partial (b) coefficients and standardized (beta) coefficients. The results in Table 2 show a high degree of consistency across the three countries in the major factors which influence the public's perception of electoral integrity. Most important is incumbency, with government supporters being most likely to see the election as fair. Views about the general level of corruption are also important in all three countries, with those seeing public officials as corrupt being more likely to also view the election as unfair. The influence of the media, in the form of watching national television, is important in Belarus and Ukraine in conveying a positive view of the election, net of other factors. ${ }^{7}$ There are only minor effects for having a Western orientation, with the exception of Belarus, where reporting having travelled to democracies is likely to increase the propensity to see the election as unfair.

[Table 2 about here]

There is, then, empirical support for three of the four hypotheses, and the consistency of the results across the three countries suggests that these are enduring effects and not a consequence of particular national circumstances. As a large literature has demonstrated, general views about society-wide corruption has an insidious effect on public opinion towards all aspects of government, regardless of how corrupt it actually is (see, for example, Clausen, Kraay and Nyiri. 2011; Cook and Gronke, 2005). It is not surprising, then, that views about corruption among public officials has a major effect on how citizens view the integrity of the electoral process.

Perhaps the most significant finding is the impact television coverage can exert on perceptions of electoral integrity, and the strong messages that it can convey about an election through the presentation of visual images. It is also notable that there is no parallel effect for newspapers. In all three countries their respective governments have gone to considerable lengths to restrict the freedom of television to report news. In Belarus there is a state monopoly on the domestic broadcast media, while international media organizations have considerable difficulty in gaining accreditation from the Information Ministry (Manaev, 
Manaeva and Yuran, 2013). The Russian broadcast media have long been subjected to government restrictions on their freedom, more recently often broadcasting frequent hagiographies of Putin while almost completely ignoring opposition candidates (de Smaele, 2013). Similar restrictions on television have also operated in Ukraine (Dyczok, 2009). The net effect of these restrictions on news reporting is that that many of those who consume more television during the election have a more positive view of the integrity of the election.

Electoral Integrity and Support for Democracy. Popular confidence in the integrity of the election process is vital for regime legitimacy. When confidence is lacking there is a large body of evidence to suggest that democratic values become weak; since the result of the election is believed to be manipulated, there is little incentive for a voter to cast a ballot or to see democracy as fair (Schedler, 2006; Birch, 2008). Electoral integrity is therefore a vital component of the democratic values that exist within a society. As Birch (2010: 1615) concludes from her study of 31 democracies, 'citizens who perceive elections to be fair are more likely to vote than those who have reservations about the conduct of electoral contests.'

In order to examine the impact of views about electoral integrity on satisfaction with democracy, Table 3 regresses the same range of independent variables that were included in Table 2, with the addition of electoral integrity, in order to predict satisfaction with democracy. ${ }^{8}$ Electoral integrity is a significant predictor of satisfaction with democracy in all three countries, as previous research has suggested. Indeed, in Belarus, the public's perception of electoral integrity is second in importance only to being a supporter of the current regime. The effect is smaller in Russia and Ukraine, but even in Russia it ranks third in importance, behind the impact of the media. Among the other factors in the model that influence satisfaction with democracy, watching national television again exerts a positive influence on the public's views in Belarus and Russia but not in Ukraine, while views of corruption among public officials undermines satisfaction in Belarus and Ukraine, but not in Russia.

[Table 3 about here]

These results confirm that electoral integrity has a strong and consistent impact on satisfaction with democracy. The findings underpin the conclusion that democratic consolidation requires an ongoing commitment among the mass public to the values and beliefs that underpin democracy, as much as to the institutions that govern it. The history of failed democracies over the last century illustrates that without such deep roots within the mass public, democratic institutions are likely to be fragile and easily usurped by charismatic leaders or radical parties intent on their destruction. Understanding the relationship between the conduct of elections and democratic values is therefore important in remedying democratic instability. 


\section{Conclusion}

The collapse of communism in 1989-90 and the transition to democracy across almost all of the postcommunist world led to the view that democracy would rapidly become entrenched. Nearly a quarter of a century on, many of these expectations remain unfulfilled. Despite rapid progress in establishing democratic institutions during the 1990s, a decade later the transition to democracy across many of these countries has either stalled or reversed. Central among the countries to experience a reversal has been Russia, together with the countries closest to it. A core principle of democracy is electoral integrity, and the widespread evidence of malpractice in these countries has provided a graphic indicator of democracy's retreat. Nor has this reversal gone unnoticed by the mass publics in these countries, as the survey data reported here illustrates.

This paper has examined the consequences of beliefs about electoral integrity for democratic values. Through an examination of survey data collected in Belarus, Russia and Ukraine, we have demonstrated that public perceptions of electoral integrity are substantially based on beliefs about corruption among public officials, on support for the current regime, and on television consumption. In turn, these beliefs about electoral integrity have a substantial impact on satisfaction with democracy. The robustness of the findings are underpinned by our measure of electoral integrity, which covers not just the counting of votes, but also access to the mass media and the conduct of the local campaign - the three major aspects of an election.

The public's beliefs about electoral integrity match closely those provided by expert judgments (see Birch, 2010; Norris, 2012). This suggests that the reform of election procedures to make them fair and transparent can change public opinion, and will have positive effects on attitudes to democracy and on electoral participation, However, the fact that these perceptions also have their roots in beliefs about more broadly based corruption among public officials suggests that the problem is broader than simply implementing electoral reform. Moreover, the apparent influence of television consumption on these attitudes indicates that open media access is an important component of reform. Overall, our results suggest dealing with the problem of electoral integrity in postcommunist societies has to be part of a broader approach to political reform across the societies as a whole; reforming the counting of votes is only one part of the process of change. Only root and branch reforms will substantially improve democratic performance. 


\section{Appendix}

Data. The 2011 Belarus survey was conducted by the Center for Sociological and Political Research at the Belarusian State University in Minsk. The survey was based on personal interviews among 1,000 respondents aged 18 years or more using a multistage stratified sample. The fieldwork took place between 5 and 11 March 2011 with a response rate of 92 percent. The 2012 Russian survey was conducted by Russian Research, based on personal interviews among 1,600 respondents aged 18 years or more using a multistage stratified sample. The fieldwork took place between 4 and 23 January 2012 with a response rate of 50 percent. The 2010 Ukraine survey was conducted by Russian Research, based on personal interviews among 1,200 respondents aged 18 years or more using a multistage stratified sample. The fieldwork took place between 15 and 24 February 2010 with a response rate of 62 percent.

Variables. Electoral integrity is a multi-item scale combining the three items in Table 1 into a single scale scored from zero (most unfair) to 10 (most fair). The mean correlations between the three items in each country and survey year are as follows. Belarus: $2000-0.58$; $2004-0.65 ; 2006-0.74 ; 2011-0.78$. Russia: $2000-0.65 ; 2004-0.57 ; 2005-0.73 ; 2008-$ $0.60 ; 2010-0.57 ; 2012-0.61$. Ukraine: $2000-0.52 ; 2006-0.61 ; 2008-0.60 ; 2010-0.68$.

In Tables 2 and 3 the variables are defined as follows. 'Satisfaction with democracy' is based on the question 'How satisfied are you with the level of democracy in [country].' 'Supports current regime' is based on the question 'Do you consider yourself a supporter or an opponent of the current government?' 'Public officials corrupt' is based on the question 'How widespread, in your opinion, are bribery and corruption in central and local government in [country]?' 'Travelled to democracies' is based on the question 'Have you ever visited any of the following countries ... ?' and is a cumulative scale for having visited the Baltic states, Poland and the United States. 'European identity' is based on the question 'Do you think of yourself as a European?' 'Reads national newspapers' and 'watches national television' are based on the question 'How often do you ... read national newspapers ... watch national TV?' There are slight wording variations in the questions across the three countries. Full details of variables, scoring and means are given in the Appendix Table.

\section{Appendix Table: Variables, Scoring, Means}

\begin{tabular}{llccc}
\hline & & \multicolumn{3}{c}{ Means } \\
\cline { 3 - 5 } \multicolumn{1}{c}{ Variable } & \multicolumn{1}{c}{ Codes } & Belarus & Russia & Ukraine \\
\hline Election fair & From 0 (unfair) to 10 (fair) & 6.42 & 5.52 & 6.40 \\
Satisfaction with & 4=very satisfied, 3=satisfied, & 2.17 & 2.93 & 2.10 \\
democracy & 2=unsatisfied, 1=very unsatisfied. & & & \\
Supports current regime & 3=supporter, 2=depends, & 2.86 & 2.15 & 1.82
\end{tabular}




\begin{tabular}{|c|c|c|c|c|}
\hline \multirow{2}{*}{ Public officials corrupt } & \multicolumn{4}{|l|}{ 1=opponent. } \\
\hline & $\begin{array}{l}4=\text { almost all officials are corrupt, } \\
3=\text { majority, } 2=\text { some, } 1=\text { hardly } \\
\text { any. }\end{array}$ & 2.50 & 3.12 & 3.30 \\
\hline Travelled to democracies & 0 to 3 & .78 & .32 & .41 \\
\hline European identity & $\begin{array}{l}4=\text { to a significant extent, } 3=\text { some } \\
\text { extent, } 2=\text { sometimes, } 1=\text { not at all }\end{array}$ & 2.30 & 1.88 & 1.69 \\
\hline Reads national newspapers & $\begin{array}{l}4=\text { regularly, } 3=\text { sometimes, } \\
2=\text { seldom, } 1=\text { never }\end{array}$ & 2.76 & 2.55 & 2.71 \\
\hline Watches national TV & $\begin{array}{l}4=\text { regularly, } 3=\text { sometimes, } \\
2=\text { seldom, } 1=\text { never }\end{array}$ & 3.29 & 3.64 & 3.63 \\
\hline Gender & $1=$ male, $0=$ female & .48 & .46 & .46 \\
\hline Age & Decades & 4.46 & 4.39 & 4.56 \\
\hline $\begin{array}{l}\text { University education } \\
\text { (N) }\end{array}$ & $1=$ yes, $0=$ no & $\begin{array}{r}.24 \\
(1,000)\end{array}$ & $\begin{array}{r}.22 \\
(1,600)\end{array}$ & $\begin{array}{c}.28 \\
(1,200)\end{array}$ \\
\hline
\end{tabular}

Sources

Belarus 2011 survey; Russian 2012 survey; Ukraine 2010 survey. 


\section{Notes}

1 The quotations come from article 15 of the Russian Constitution.

2 The rankings from 1999 until 2013 are available at www.freedomhouse.org, last accessed 4 March 2013.

3 This assumes, of course, that respondents could differentiate between such a detailed list.

$4 \quad$ A fourth item, 'representing people with different views', was included in most of the surveys, but because it was not consistently asked it has been excluded. In any event, preliminary analysis showed that the addition of this fourth item did not add significantly to the overall reliability of the multiple-item scale.

5 The mean inter-item correlation in Belarus is .69, in Russia .62, and in Ukraine .60. The correlations for each year are given in the Appendix.

6 The choice of countries that the respondents reported travelling to was governed by what was available consistently in all three countries.

7 Measuring television consumption is, of course, difficult since within each country a variety of television channels from other countries can be accessed by cable, a pattern of behaviour which may be associated with ethno-linguistic identification. We are grateful to a reviewer for pointing out this possibility.

8 We assume that the causality operates from electoral integrity to satisfaction with democracy. An alternative possibility is that satisfaction with democracy shapes views of electoral integrity. The causality cannot be definitively identified from the type of cross-sectional data used here, but our interpretation is supported by other research in this area (see, for example, Linde, 2012). 


\section{References}

Alvarez, R. Michael, Thad E. Hall and Susan Hyde. 2008. Election Fraud: Detecting and Deterring Electoral Manipulation. Washington, DC: Brookings Institute.

Anderson, Christopher J., André Blais, Shaun Bowler, Todd Donovan, and Ola Listhaug. 2005. Losers' Consent: Elections and Democratic Legitimacy. Oxford: Oxford University Press.

Birch, Sarah. 2008. 'Electoral Institutions and Popular Confidence in Electoral Processes: A Cross-National Analysis.' Electoral Studies 27: 305-20.

Birch, Sarah. 2010. 'Perceptions of Electoral Fairness and Voter Turnout.' Comparative Political Studies 43: 1601-22.

Birch, Sarah. 2012. Electoral Malpractice. Oxford: Oxford University Press.

Blais, André, 2000. To Vote or Not to Vote: The Merits and Limits of Rational Choice Theory. Pittsburgh, PA: University of Pittsburgh Press.

Carothers, Thomas. 2002. 'The End of the Transition Paradigm.' Journal of Democracy13: 5-21.

Clausen, Bianca, Aart Kraay and Zsolt Nyiri. 2011. 'Corruption and Confidence in Public Institutions: Evidence from a Global Survey.' World Bank Economic Review 25: 212-249.

Cook, Timothy E. and Paul Gronke. 2005. 'The Skeptical American: Revisiting the Meanings of Trust in Government and Confidence in Institutions.' Journal of Politics 67: 784-803.

Council of Europe. 2007. Observation of the Parliamentary Elections in the Russian Federation (2 December 2007). Council of Europe Parliamentary Assembly, 20 December 2007, doc. 11473.

Council of Europe. 2008. Observation of the Presidential Election in the Russian Federation (2 March 2008). Council of Europe Parliamentary Assembly, 17 March 2008, doc. 11536.

Dyczok, Marta. 2009. 'Do the Media Matter? Focus on Ukraine.' In Marta Dyczok and Oxana Gaman-Golutvina, eds. Media, Democracy and Freedom: The Postcommunist Experience. Bern: Peter Lang.

Galbreath, David J. and Richard Rose. 2008. 'Fair Treatment in a Divided Society: A Bottom-Up Assessment of Bureaucratic Encounters in Latvia.' Governance 21: 53-73.

Holmes, Leslie. 2006. Rotten States? Corruption, Post-Communism and Neoliberalism. Durham, NC: Duke University Press.

Hyde, Susan. D. 2011. The Pseudo-Democrat's Dilemma. Ithaca, NJ: Cornell. 
Karklins, Rasma. 2005. The System Made Me Do It: Corruption in Postcommunist Societies. New York: M E Sharpe.

Kelley, Judith. 2012. Monitoring Democracy: When International Election Observation Works and Why it Often Fails. Princeton, NJ: Princeton University Press.

Levitsky, Steven and Lucan A. Way. 2010.Competitive Authoritarianism. Hybrid Regimes After The Cold War. Cambridge: Cambridge University Press.

Lindberg, Staffan (ed). 2009. Democratization by Elections: A New Mode of Transition. Baltimore, MD: The Johns Hopkins University Press.

Linde, Jonas. 2012. 'Why Feed the Hand that Bites You? Perceptions of Procedural Fairness and System Support in Post-Communist Democracies.' European Journal of Political Research 51: 410-434.

Linz, Juan J. and Alfred Stepan. 1996. Problems of Democratic Transition and Consolidation. Baltimore, MD: The Johns Hopkins Press.

McAllister, Ian and Stephen White. 2011. 'Public Perceptions of Electoral Fairness in Russia.' Europe-Asia Studies 63: 663-83.

Manaev, Oleg, Natalie Manaeva and Dzmitry Yuran. 2013. "'Islands in the Stream": Reflections on Media Development in Belarus.' In Peter Gross and Karol Jakubowicz, eds. Media Transformation in the Postcommunist World. Lanham, MD: Lexington.

Mendras, Marie. 2012.Russian Politics: The Paradox of a Weak State. London: Hurst.

Myagkov, Mikhail, Peter C. Ordeshook, and Dmitry Shakin. 2009. The Forensics of Election Fraud: Russia and Ukraine. New York: Cambridge University Press.

Norris, Pippa. 2012. 'Are There Global Norms and Universal Standards of Electoral Integrity and Malpractice? Comparing Public and Expert Perceptions.' Unpublished paper.

OSCE. 2000. Russian Federation. Elections to the State Duma 19 December 1999. Final Report. Warsaw: OSCE.

OSCE. 2004. Russian Federation. Elections to the State Duma 7 December 2003. OSCE/ODIHR Election Observation Mission Report. Warsaw: OSCE, 2004.

OSCE. 2007. Ukraine. Pre-Term Parliamentary Elections 30 September 2007. OSCE/ODIHR Election Observation Mission Report. Warsaw: ODIHR.

OSCE. 2010. Ukraine. Presidential Election 17 January and 7 February 2010. OSCE/ODIHR Election Observation Mission Final Report. Warsaw: OSCE.

OSCE. 2011. Republic of Belarus. Presidential Election 19 December 2010. OSCE/ODIHR Election Observation Mission Final Report. Warsaw: OSCE, 2011.

OSCE. 2012. Russian Federation. Elections to the State Duma 4 December 2011. OSCE/ODIHR Election Observation Mission Final Report. Warsaw: OSCE. 
OSCE. 2013. Ukraine: Parliamentary Elections 28 October 2012. OSCE/ODIHR Election Observation Mission Final Report. Warsaw: ODIHR, 2013.

Rose, Richard. 2012. New Russia Barometer XIX: The 2011 Duma Election. Glasgow: Centre for the Study of Public Policy, University of Strathclyde.

Rose, Richard and William Mishler. 2009. 'How Do Electors Respond to an "Unfair" Election? The Experience of Russians.' Post-Soviet Affairs 25: 118-136.

Rothstein, Bo. 2009. 'Creating Political Legitimacy: Electoral Democracy Versus Quality of Government.' American Behavioral Scientist 53: 311-330.

Schedler, Andreas. 2002. 'The Menu of Manipulation.' Journal of Democracy 13: 36-50.

Schedler, Andreas (ed). 2006. Electoral Authoritarianism: The Dynamics of Unfree Competition. Boulder, CO: Lynne Rienner.

Shlapentokh, Vladimir. 2007.Contemporary Russia as a Feudal Society: A New Perspective on the Post-Soviet Era. New York: Palgrave Macmillan.

de Smaele, Hedwig. 2013. 'Russian Media and Democracy'. In Peter Gross and Karol Jakubowicz, eds. Media Transformation in the Postcommunist World. Lanham, MD: Lexington.

Transparency International. 2012. Corruptions Perceptions Index 2012. Available from www.transparency.org. Accessed 4 March 2013.

White, Stephen et al. 2012. Russia's Authoritarian Elections. London: Routledge. 
Figure 1: Perceived Corruption Among Public Officials, 2000-12

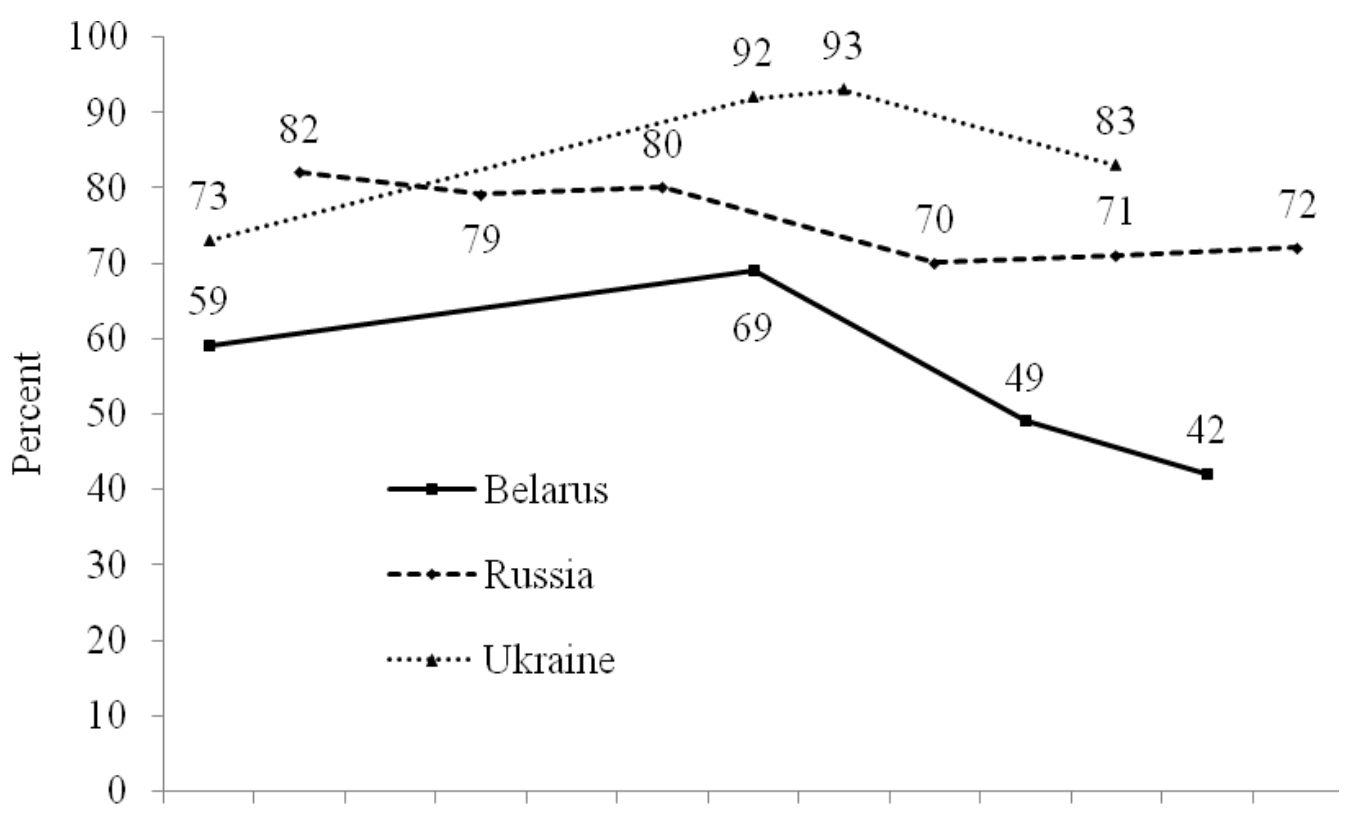

2000200120022003200420052006200720082009201020112012

The question was: 'How widespread, in your opinion, are bribery and corruption in central and local government in [country]?' Estimates combine 'most officials are corrupt' and 'almost all officials are corrupt'.

Sources Belarus 2000, 2004, 2006, 2011 surveys; Russia 2000, 2004, 2005, 2008, 2010, 2012 surveys; Ukraine 2000, 2006, 2008, 2010 surveys. 
Table 1: Perceptions of Electoral Fairness in Belarus (2011), Russia (2012) and the Ukraine (2010)

\begin{tabular}{|c|c|c|c|c|c|c|c|c|c|}
\hline & \multicolumn{3}{|c|}{ Counting votes } & \multicolumn{3}{|c|}{ TV campaign coverage } & \multicolumn{3}{|c|}{ Local campaign } \\
\hline & Belarus & Russia & Ukraine & Belarus & Russia & Ukraine & Belarus & Russia & Ukraine \\
\hline Definitely fair & 35 & 17 & 27 & 32 & 19 & 26 & 34 & 17 & 30 \\
\hline Somewhat fair & 30 & 35 & 37 & 33 & 40 & 41 & 33 & 35 & 34 \\
\hline Not very fair & 17 & 24 & 19 & 19 & 21 & 19 & 15 & 24 & 17 \\
\hline Not fair at all & 10 & 15 & 5 & 10 & 12 & 5 & 8 & 13 & 5 \\
\hline Don't know & 8 & 9 & 12 & 6 & 8 & 9 & 10 & 11 & 14 \\
\hline $\begin{array}{l}\text { Total } \\
(\mathrm{N})\end{array}$ & $\begin{array}{c}100 \\
(1,000)\end{array}$ & $\begin{array}{c}100 \\
(1,605)\end{array}$ & $\begin{array}{c}100 \\
(1,200)\end{array}$ & $\begin{array}{c}100 \\
(1,000)\end{array}$ & $\begin{array}{c}100 \\
(1,605)\end{array}$ & $\begin{array}{c}100 \\
(1,200)\end{array}$ & $\begin{array}{c}100 \\
(1,000)\end{array}$ & $\begin{array}{c}100 \\
(1,605)\end{array}$ & $\begin{array}{c}100 \\
(1,200)\end{array}$ \\
\hline
\end{tabular}

The question was: 'In your opinion, to what extent are elections in Ukraine fair in relation to ... the composition of the ballot paper and counting votes ... television coverage of the election campaign ... the conduct of the electoral campaign in your district?'

Sources Belarus 2011 survey; Russian 2012 survey; Ukraine 2010 survey. 
Figure 2: Perceived Fairness in the Conduct of Elections, 2000-12

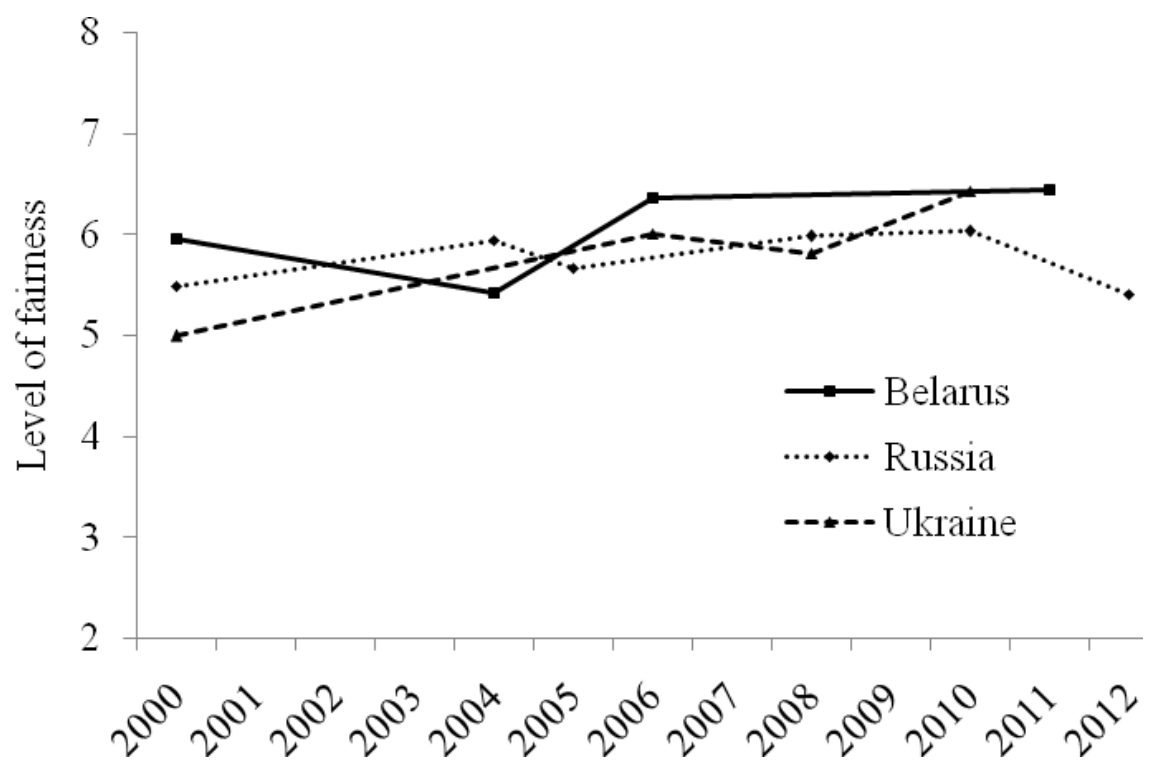

Scores combine items relating to the fairness of counting votes, TV coverage, and the local campaign.

Sources Belarus 2000, 2004, 2006, 2011 surveys; Russia 2000, 2004, 2005, 2008, 2010, 2012 surveys; Ukraine 2000, 2006, 2008, 2010 surveys. 
Table 2: Explaining the Public's Views of Electoral Integrity

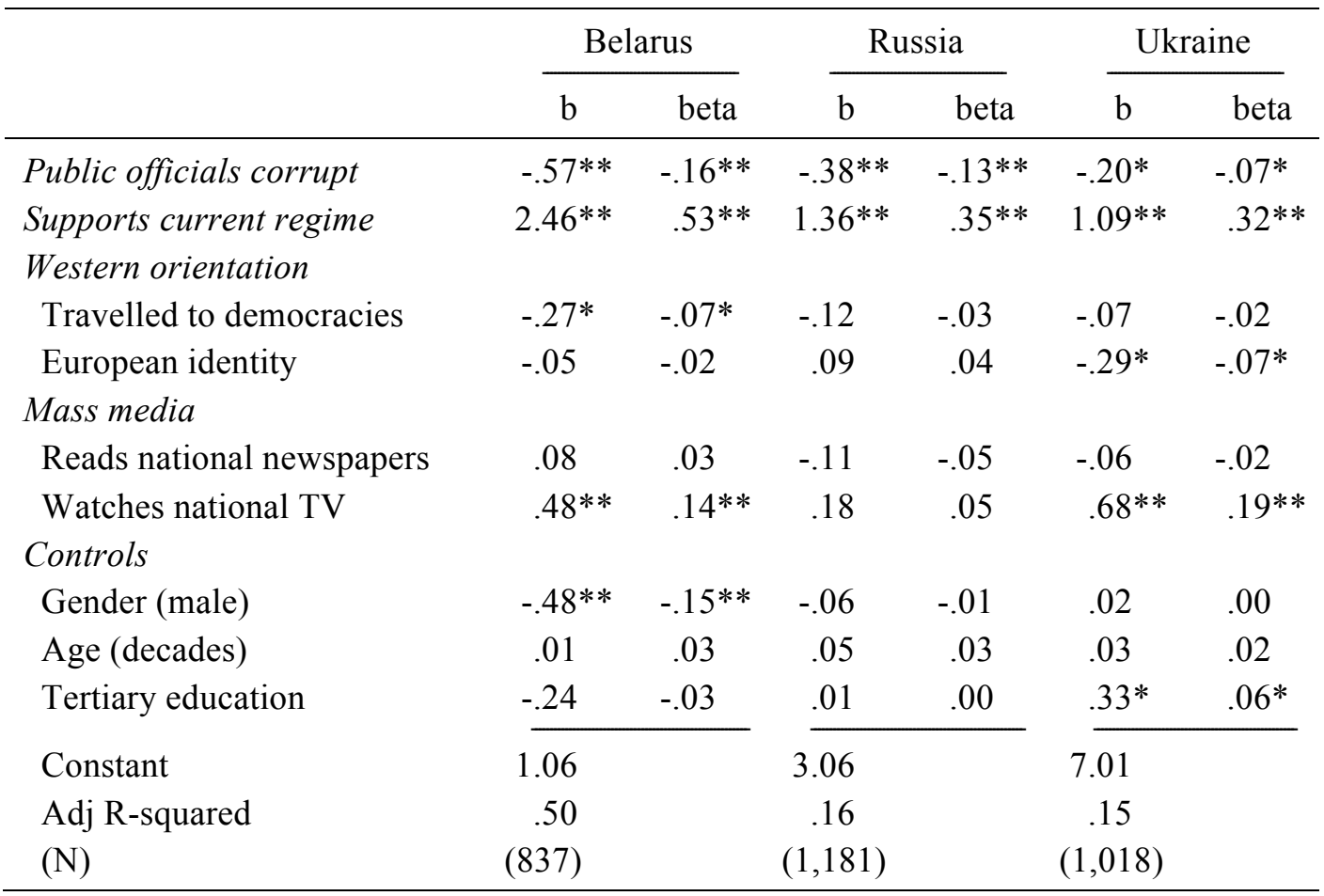

**, statistically significant at $\mathrm{p}<.01, * \mathrm{p}<.05$.

Ordinary least squares regression showing partial (b) and standardized (beta) coefficients predicting the probability of seeing an election as fair. The dependent variable is scored zero to 10 , see Appendix for details of the independent variables.

Sources Belarus 2011 survey; Russian 2012 survey; Ukraine 2010 survey. 
Table 3: Electoral Integrity and Satisfaction with Democracy

\begin{tabular}{|c|c|c|c|c|c|c|}
\hline & \multicolumn{2}{|c|}{ Belarus } & \multicolumn{2}{|c|}{ Russia } & \multicolumn{2}{|c|}{ Ukraine } \\
\hline & $\mathrm{b}$ & beta & $\mathrm{b}$ & beta & $\mathrm{b}$ & beta \\
\hline Electoral integrity & $.09 * *$ & $.31 * *$ & $.02 *$ & $.07 *$ & $.03 *$ & $.06^{*}$ \\
\hline Public officials corrupt & $-.13 * *$ & $-.13 * *$ & -.04 & -.04 & $-.12 * *$ & $-.12 * *$ \\
\hline Supports current regime & $.45 * *$ & $.33 * *$ & .05 & .05 & $.17 * *$ & $.15^{* *}$ \\
\hline \multicolumn{7}{|l|}{ Western orientation } \\
\hline Travelled to democracies & .01 & .01 & .04 & .03 & .01 & .01 \\
\hline European identity & $.06^{* *}$ & $.07 * *$ & .02 & .03 & .00 & .00 \\
\hline \multicolumn{7}{|l|}{ Mass media } \\
\hline Reads national newspapers & -.02 & -.02 & $-.07 * *$ & $-.09 * *$ & -.42 & -.05 \\
\hline Watches national TV & $.08 * *$ & $.08 * *$ & $.12 * *$ & $.11^{* *}$ & .03 & .03 \\
\hline \multicolumn{7}{|l|}{ Controls } \\
\hline Gender (male) & .02 & .01 & -.06 & -.04 & .01 & .01 \\
\hline Age (decades) & $.01^{*}$ & $.06^{*}$ & -.01 & -.02 & -.01 & -.02 \\
\hline Tertiary education & $-.19 * *$ & $-.10 * *$ & .03 & .02 & $.12 *$ & $.07^{*}$ \\
\hline Constant & .70 & & 2.99 & & 2.22 & \\
\hline Adj R-squared & .50 & & .04 & & .05 & \\
\hline$(\mathrm{N})$ & (837) & & $(1,181)$ & & $(1,018)$ & \\
\hline
\end{tabular}

**, statistically significant at $\mathrm{p}<.01, * \mathrm{p}<.05$.

Ordinary least squares regression showing partial (b) and standardized (beta) coefficients predicting the probability of seeing an election as fair. The dependent variable is scored zero to 10, see Appendix for details of the independent variables.

Sources Belarus 2011 survey; Russian 2012 survey; Ukraine 2010 survey. 